\title{
IMPLEMENTASI ZAKAT HASIL PERTANIAN DALAM PERSPEKTIF HUKUM ISLAM (STUDI DI DESA ANJANI KECAMATAN SURALAGA KABUPATEN LOMBOK TIMUR)
}

\author{
Yuli Hauliatin Nahdlah \\ Institut Agama Islam Hamzanwadi NW Lombok Timur \\ Email: nahdlah01@gmail.com
}

\begin{abstract}
Abstrak: Tujuan dari penelitian ini adalah untuk mengetahui pelaksanaan zakat hasil pertanian yang ada di Desa Anjani Kecamatan Suralaga Kabupaten Lombok Timur dan mengetahui pandangan hukum Islam terhadap praktek zakat hasil pertanian yang dilakukan masyarakat. Adapun Jenis penelitian ini adalah penelitian lapangan (field research) yang dilaksanakan di Desa Anjani Kecamatan Suralaga Kabupaten Lombok Timur. Hasil penelitian menunjukkan bahawa petani di Desa Anjani Kecamatan Suralaga Kabupaten Lombok Timur sudah menjalankan kewajiban yaitu mengeluarkan zakat harta. Zakat yang di keluarkan oleh para petani yaitu 10\%, 5\%, dan 2,5\%, sesuai dengan prosentase pengetahuan mereka masing-masing. Zakat yang dikeluarkan oleh para petani di Desa Anjani Kecamatan Suralaga Kabupaten Lombok Timur tidak sesuai dengan ketentuan-ketentuan atau syarat dalam zakat pertanian yang telah ditentuakan dalam hukum Islam. Seharusnya pelaksanaan zakatnya mengacu pada aturan tata cara pelaksanaan zakat pertanian dengan teknik perhitungan $10 \%$ untuk pertanian yang diairi dengan air hujan dan irigasi dan $5 \%$ untuk pertanian yang diairi dengan bantuan manusia.
\end{abstract}

Kata kunci: Hukum Islam \& Zakat Hasil Pertanian

Abstract: The purpose of this study is to determine the implementation of zakat on agricultural products in Anjani Village, Suralaga District, East Lombok Regency and to find out the Islamic law's view of the zakat practice of agricultural products by the community. The type of this research is field research conducted in Anjani Village, Suralaga District, East Lombok Regency. The results showed that farmers in Anjani Village, Suralaga Subdistrict, East Lombok Regency had fulfilled the obligation to pay zakat on assets. The zakat issued by the farmers is $10 \%, 5 \%$, and $2.5 \%$, according to the percentage of their respective knowledge. The zakat issued by farmers in Anjani Village, Suralaga Subdistrict, East Lombok Regency is not in accordance with the terms or conditions in agricultural zakat that have been stipulated in Islamic law. The implementation of zakat should be based on the rules for the implementation of zakat on agriculture with a technique of calculating $10 \%$ for agriculture irrigated with rain and irrigation water and 5\% for agriculture irrigated with human assistance.

Keywords: Islamic Law and Zakat on Agricultural Products 


\section{PENDAHULUAN}

Saat ini ada kondisi yang menyedihkan karena ternyata masih banyak umat Islam di Indonesia ini yang dirundung berbagai persoalan hidup, antara lain, kemiskinan dan kebodohan, dengan segala keterbatasannya mereka benar-benar tak berdaya untuk bangkit mencapai kehidupan yang lebih baik dan berkualitas.Yang lebih memprihatinkan lagi, mereka ini berada di tengah-tengah sebagian kecil masyarakat yang kehidupannya sangat berkualitas, bahkan berlimpah kemewahan. Karena para aghniya'atau para hartawan ini tidak memperdulikan nasib si miskin, maka akhirnya terjadilah kesenjangan sosial yang melebar. Zakat sebagai salah satu solusi mengatasi persoalan kemiskinan dan ketidak berdayaan umat, dijalankan bukanlah sekedar untuk membina hubungan baik antara si kaya dan si miskin, tapi juga untuk meningkatkan produktifitas umat.Dilihat dari latar belakang penduduk Indonesia banyaknya penduduk atau tenaga kerja yang hidup atau bekerja pada sektor pertanian atau dari produk yang berasaldari pertanian, maka dapat disimpulkan bahwa potensi zakat pertanian di Indonesia sangatlah besar. Artinya, dana zakat pertanian yang potensianya luar biasa besar di Indonesia ini, harus didayagunakan sehingga mampu membangkitkan umat dari keterpurukan.

Zakat adalah poros dan pusat keuangan Negara Islam, Zakat meliputi bidang moral, sosial dan ekonomi. Dalam bidang moral zakat mengikis habis ketamakan dan keserakahan orang kaya. Dalam bidang sosial, zakat bertindak sebagai alat khas yang diberikan Islam untuk menghapuskan kemiskinan dari masyarakat dengan menyadarkan orang kaya akan tanggung jawab sosial yang mereka miliki. Dalam bidang ekonomi, zakat mencegah penumpukan kekayaan yang mengerikan dalam tangan segelintir orang dan memungkinkan kekayaan untuk disebarkan sebelum sempat menjadi besar dan sangat berbahaya di tangan para pemiliknya. Zakat merupakan sumbangan wajib kaum muslimin untuk pembendaharaan Negara (Mardani, $2011: 35$ ).

Di lingkungan masyarakat ada banyak permasalahan yang timbul dan terjadi, ketidaksesuaian antara teori dan praktek memberikan dampak hukum baik secara individu maupun kelompok, terutama pada pemahaman mereka terhadap nilai-nilai prinsip seperti religiusitas dan nilai-nilai sosial kemasyarakatan yang terus berkembang cepat sebagai suatu nilai yang dinamakan sebagai nilai kemodernan (modernitas).

Dari pemaparan diatas menunjukkan bahwa pertanian adalah bagian penting dalam meningkatkan zakat, karena maju atau mundurnya sektor pertanian akan berpengaruh pada pencapaian zakat hasil pertanian. Sehingga bidang pertanian perlu mendapat perhatian yang lebih dari semua pihak, termasuk pemerintah agar potensi dari petani untuk membayar zakat pertanian semakin besar serta pencapaian tujuan zakat yang 
sebenarnya yaitu kesejahteraan umat juga tercipta dengan baik dan efisien. Karena dengan majunya sektor pertanian, maka tingkat hasil yang diperoleh semakin meningkat, sehingga potensi pembayaran zakatnya juga semakin meningkat juga, serta tingkat kesejahteraan masyarakat juga akan lebih merata.

Desa Anjani adalah salah satu desa yang berada di Kecamatan Suralaga Kabupaten Lombok Timur yang rata-rata penduduknya bekerja pada sektor pertanian. Luas lahan persawahan di Desa Anjani yaitu kurang lebih $93 \mathrm{Ha}$ dimana lahan persawahan tersebut rata-rata ditanami padi. Karena mayoritas masyarakatnya menjadi petani, maka para petani menggantungkan hidupnya dari hasil pertanian yang mereka dapatkan.

Selama ini pengelolaan zakat pertanian di Desa Anjani belum di kelola dengan baik. Dalam kenyataan di masyarakat bahwa kesadaran untuk membayar zakat pertanian dalam hal ini tanaman padi masih sangat kurang. Mengingat bahwa pengetahuan dan pemahaman masyarakat petani Desa Anjani masih banyak yang belum paham tentang zakat pertanian, terutama zakat tanaman padi.Karena selama ini yang mereka lakukan masih sebatas memberikan sedikit bagian dari hasil panen yang didapatkan kepada tetangga atau saudara tanpa memperhatikan pihak yang wajib menerima zakat (mustahik). Anggapan mereka bahwa dengan memberikan sedikit bagian tersebut sudah menggantikan zakat dan juga sebagai wujud rasa syukur mereka atas hasil panen yang didapatkan.

\section{METODE PENELITIAN}

Jenis penelitian ini termasuk dalam jenis penelitian lapangan (field research) dengan menggunakan metode penelitian kualitatif. Metode penelitian kualitatif sering disebut metode penelitian naturalistik karena penelitiannya dilakukan pada kondisi yang alamiah, disebut juga sebagai metode etnografi. Penelitian kualitatif dilakukan pada objek alamiah yang berkembang apa adanya, tidak dimanipulasi oleh peneliti dan kehadiran peneliti tidak begitu mempengaruhi dinamika pada objek tersebut (Sugiyono, 2009:4).

Penelitian kualitatif instrumennya adalah peneliti itu sendiri. Menjadi instrumen, maka peneliti harus memiliki bekal teori dan wawasan luas, sehingga mampu bertanya, menganalisis, memotret, dan mengkonstruksi situasi sosial yang diteliti menjadi lebih jelas dan bermakna. Penelitian ini merupakan penelitian deskriptif kualitatif.

\section{PEMBAHASAN}

Hasil penelitian ini menunjukkan bahwa salah satu Tokoh Pemuka Agama di Desa Anjani yaitu Bapak Mastur menuturkan bahwa pemahaman tentang zakat pertanian yang ada di Desa Anjani yaitu berdasarkan hasil tanaman padi. Dimana jika pengairannya menggunakan pengairan dengan air yang mengalir atau tanpa mengeluarkan biaya, maka batas seorang petani itu wajib untuk 
mengeluarkan zakat tanaman yaitu 1 ton padi basah, dengan besarnya zakat yang dikeluarkan yaitu $1 \mathrm{kw}$ padi. Kemudian jika pengairannya menggunakan mesin atau memerlukan biaya, maka batasnya untuk berzakat yaitu seperempat dari $1 \mathrm{kw}$ tadi. Jika dalam bentuk beras, maka setiap $8 \mathrm{kw}$ beras wajib dikeluarkan zakat sebesar $1 \mathrm{kw}$ beras juga. Jadi, jika seorang petani hasil panennya tidak mencapai 1 ton padi, maka dia tidak dikenakan wajib zakat, begitu juga jika seorang petani hasil panennya setelah diselep tidak mencapai $8 \mathrm{kw}$ beras, maka dia juga tidak dikenakan wajib zakat. Jika hasil panen ditebas atau dijual, maka zakatnya yaitu sama berdasarkan sistem pengairannya. Jika pengairannya tanpa mengeluarkan biaya wajib mengeluarkan sepersepuluh dari hasil uang tebasan, dengan dibatasi sejumlah satu juta rupiah ( $\operatorname{Rp~1.000.000,-),~dan~jika~sistem~}$ pengairannya menggunakan mesin atau memerlukan biaya maka hasil dari sepersepuluh tadi dibagi lagi dengan 4 (empat).

Zakat hasil tanaman ini wajib dikeluarkan bagi yang mendapatkan hasil tanamannya, baik itu petani sendiri, penggarap, atau buruh tani yang menyewa lahan. Selain itu, untuk mengeluarkan zakat hasil tanaman ini tanpa dikurangi dengan biaya-biaya lain terlebih dahulu, melainkan hasil dari pertanian tersebut dihitung zakatnya dahulu, baru kemudian hasil bersih setelah dikeluarkan zakat tersebut adalah hasil yang bisa dipergunakan oleh petani untuk kebutuhan hidupnya. Namun, jika pertanian tersebut merupakan pertanian maro (dibagi dua), maka hasilnya dibagi dua setelah zakatnya dikeluarkan.

Pelaksanaan Zakat Pertanian di Desa Anjani Berdasarkan data yang diperoleh oleh peneliti diketahui bahwa pemahaman masyarakat tentang zakat pertanian masih sangat kurang. Seperti halnya Bapak Samsudin, Bapak Busairin dan Bapak Zainul Arifin yang mereka pahami hanyalah pada pengkategorian zakatnya, bahwa yang mereka pahami adalah zakat pertanian sama dengan zakat mal, sehingga ketika mereka mendapatkan panen dan hanya mengeluarkan 2,5\% saja. Sementara Bapak Muhammad Azhar tidak mengetahui tentang ketentuan-ketentuan apa saja untuk bisa mengeluarkan zakat pertanian. Karena itu, Bapak Muhammad Azhar saat setelah panen hanya memberikan sebagian beras kepada para tetangga yang tidak mampu sebagai bentuk rasa syukur atas hasil panennya.

Lain halnya dengan Bapak Zaenudin, Abdurrahman, dan Taufiqurrahman bahwa dia mengetahui adanya kewajiban megeluarkan zakat setelah panen serta ketentuan zakat setelah panen, namun Bapak Zaenudin tidak melaksanakannya dengan alasan hasil panennya tidak cukup untuk membayarkan kebutuhan hidup keluarganya. Bapak Zaenudin kurang memiliki kesadaran untuk mengeluarkan sebagian dari hasil panennya untuk berzakat.Hanya Bapak Mastur saja dari narasumber yang peneliti wawancarai yang 
memahami dan selalu membayarkan zakatnya sesuai dengan ketentuan-ketentuan Islam.

Dalam penyaluran atau pendistribusian zakat tersebut, mereka langsung memberikan kepada orang-orang fakir yang ada di lingkungan sekitarnya, serta harta tersebut mereka bagikan juga kepada saudara-saudara mereka sendiri.Jadi dalam penyaluran zakat tersebut masih belum sesuai dengan syari'at Islam. Di Desa Anjani memang tidak ada lembaga amil khusus yang mengelola zakat, kecuali lembaga-lembaga amil zakat yang ada di setiap Masjid setempat. Dulu pernah ada BAZDES yang dibentuk sekitar 5 tahun yang lalu, namun itu tidak berjalan dengan optimal sesuai dengan yang diharapkan karena kurangnya dukungan masyarakat ditambah lagi dengan orang-orang yang duduk dalam kepengurusan BAZDES tidak bisa bekerja dengan professional karena kurangnya pengetahuan tentang pengelolaan zakat itu sendiri khususnya zakat pertanian. Keadaan ini semakin diperparah dengan belum adanya komitmen dari pemerintah desa untuk melanjukan adanya lembaga zakat tersebut.Bahkan sampai sekarang bahkan banyak masyarakat yang tidak mengetahui bahwa pernah ada lembaga yang mengurus urusan zakat di desanya. Harusnya dengan kehadiran lembaga zakat tersebut mampu menjadi hal baik bagi pemerataan kesejahteraan masyarakat di desa.Sehingga dari potensi-potensi zakat yang ada dapat menjadi sarana pengentasan kemiskinan yang ada di Desa Anjani.
Dengan demikian, pelaksanaan penunaian zakat pertanian di Desa Anjani Kecamatan Suralaga Kabupaten Lombok Timur sebagian besar masih kurang sesuai dengan syari'at Islam, karena mereka hanya mengeluarkan zakat sebagai infaq dan sedekah saja.Namun ada yang penunaian zakatnya sudah sesuai dengan syari'at Islam. Selain itu, penyaluran zakat hasil pertanian di Desa Anjani masih ada yang belum sesuai dengan ketentuan syari'at Islam, karena dalam memberikan zakatnya mereka masih menggunakan takisran secara pribadi, tidak disesuaikan dengan ketentuan yang ada dalam fiqih. Seperti yang sudah diketahui dari awal, terdapat petani yang tidak megetahui ketentuan-ketentuan zakat sebagaimana yang telah ditetapkan. Masyarakat petani Desa Anjani banyak memberikan sebagian dari hasil panennya tanpa menghitung terlebih dahulu apakah hasil panen tersebut sudah mencapai satu nisab atau belum, walaupun ada beberapa dari petani yang menghitung terlebih dahulu.

Kondisi tersebut tidak boleh dibiarkan terus menerus terjadi apalagi masyarakat Desa Anjani mayoritas bahkan seratus persen beragama Islam, yang artinya segala aktivitas yang dilakukan baik menyangkut syariah, muamalah, dan hukumah harus sesuai dengan ketentuan-ketentuan yang telah digariskan dalam al-Qur`an dan al-Hadits serta rujukan pendapat para Ulama' dalam hal ini empat Imam Mazhab yang ada yakni Hanafi, Maliki, Syafi i, dan Imam Hambali. Hal tersebut 
sangat penting untuk dilakukan karena dari sisi perekonmian potensi zakat juga memberikan kontribusi yang sangat besar dalam memberdayakan dan meningkatkan kesejahteraan masyarakat terutama ummat Islam.

\section{SIMPULAN}

Dalam membayarkan zakatnya, petani di Desa Anjani ada yang sudah membayarkan sesuai dengan ketentuan dalam syari'at Islam. Namun, juga terdapat petani yang dalam membayarkan zakatnya belum sesuai dengan ketentuan dalam syari'at Islam, bahkan ada juga petani yang tidak membayarkan zakatnya sama sekali setelah panen. Di Desa Anjani pernah ada Lembaga Amil Zakat yang dibentuk, tetapi sebagian besar masyarakat Desa Anjani tidak mengetahui keberadaannya sehingga masyarakat mengeluarkan kewajiban zakatnya secara perorangan kepada warga yang berhak menerianya tanpa disalurkan melalui Lembaga Amil Zakat yang ada di desa setempat.

\section{DAFTAR PUSTAKA}

Abdurrahman, Muhammad Bin. 2017. Fiqih Empat Mazhab. Bandung: Hasyimi.

Al-Ghazali. 1994. Rahasia Puasa dan Zakat, Bandung: Karisma.

Aliy As'ad. 1979. Terjemah Fathul Mu'in, Yogyakarta: Menara Kudus.

Amin Mansyur. 2000. Pengelolaan Zakat dan Permasalahannya di Indonesia. Direktorat Urais Departemen Agama.
Anshori, Abdul Ghofur. 2006. Hukum dan Pemberdayaan Zakat, Yogyakarta: Pilar Media.

Daim, Sudarman. 2002. Menjadi Peneliti Kualitatif. Bandung: CV.Pustaka Seia.

Dpartemen Agama Republik Indonesia. 2010. Al-Qur'an dan terjemahannya. Bandung: Diponegor.

Elsi, Kartika. 2006. Pedoman Pengelolaan Zakat. Semarang: UNNES Press.

Fakhrudin. 2008. Fiqih dan Manajemen Zakat di Indonesia. Malang: UIN Malang Press.

Ghaniy, Taqiyuddin Abdul. 2011. HaditsHadits Shahih Seputar Hukum. Jakarta: Republika.

Hafidhuddin, Didin. 2007. Zakat dalam Perekonomian Moderen. Jakarta: Gema Insani Press.

Hasan M. Ali. 2006. Zakat dan Infak. Jakarta: Kencana Prenada Media.

Hasan, bin Ahmad. 2004. Taqriratussadidah Fil Masail Mufidah. Surabaya: Darul Ulum Al-Islamiah.

Kamil, Muhammad Uwaidah. 2007. Fiqih Wanita. Jakarta: Pustaka Al-Kautsar.

Maghfiroh, Mamluatul. 2007. Zakat. Jakarta: Departemen Agama RI.

Mardani. 2011. Hukum Ekonomi Syariah di Indonesia. Bandung: Refika Aditama.

Muhammad, Daud Ali. 1998. Sistem Ekonomi Islam, Zakat dan Waqaf, Jakarta: Universitas Indonesia Press.

Mukhtar. 2013. Metode Praktis Penelitian Deskriptif Kualitatif. Jakarta: Referensi. 
Mursyidi. 2006. Akuntansi dan Zakat Kontemporer. Bandung: PT. Remaja Rosdyakarya.

Partanto, Dahlan. 2011. Kamus Ilmiah Populer. Surabaya: Arkola.

Permon. 2005. Formula Zakat Menuju Kesejahteraan Sosial. Surabaya: Aulia.

Ruslan, Ibnu. 2010. Terjemah Matan Zubad. Surabaya: Mutiara Ilmu.

Salim \& Abdullah. 1992. Terjemah Bulugul Maram MinAdillatil Ahkam. Surabaya: Balai Buku.

Sudjana, Nana. 2013. Tuntunan Penyusunan Karya Ilmiah. Bandung: Sinar Baru Algensindo.

Uqaily, Mahmud Ali. 2010. Praktis \& Mudah Menghitung Zakat. Solo: Aqwam.

Yusuf, Al-Qardhawi. 1987. Hukum Zakat. Jakarta: Pustaka Lentera Antar Nusa. 